\title{
PENGARUH METODE LEARNING START WITH A QUESTION (LSQ) TERHADAP PENINGKATAN KEMAMPUAN BERPIKIR KRITIS SISWA PADA MATERI EKOSISTEM
}

\author{
Rizka Robiatul Addawiyah, Idad Suhada dan Muhammad Muttaqien \\ Program Studi Pendidikan Biologi, Program Sarjana S1, Universitas Islam Negeri \\ Sunan Gunung Djati Bandung
}

\begin{abstract}
The study was conducted in class VII-Purwakarta MTsN Plered on ecosystems material. Based on direct observation and interviews with teachers in MTs.N Plered that the activity of the class students are less active, critical thinking skills of students in the lower grade and variation model of applied learning teacher less. So that students actively in class and increase students' critical thinking skills used method Start Learning With A Question in the learning process. This study aims to determine the enforceability of the learning process by applying learning methods start with a question. Increasing students' critical thinking skills, and student responses to learning using learning methods start with a question on the material ecosystem. The framework of this research that students are required to actively ask especially at the beginning of the learning process of the student asks a thought process that is carried out in order to solve the problems of students in learning. This learning process with such students will be active in class and critical thinking would be formed. Method Start Learning With A Question is an active learning method in asking, where students are directly involved in the learning process. Active asked at the beginning of the learning will stimulate students to think critically about the material to be conveyed. From the data processing gained an average of N-Gain increase students' critical thinking skills in the experimental class 0.54 and the control class 0.49 . To look significantly on the ability of critical thinking among students learning with Learning methods Start With A Question and without using the Start Learning With A Question presented through pretest and posttest values as well as the NGain. To prove this hypothesis significance test was used to test $t$ nomalitas first tested and homogeneity. Because one of the data is not normal, the Mann-Whitney test. Based on the results of Mann-Whitney test scores N-Gain between the experimental class and the control class result that Zhitung > Ztabel. thus Zhitung> Ztabel ie 1.98>1.65; Ho is rejected and Ha accepted meaning there is influence between the $\mathrm{N}$-Gain pretest and posttest experimental class with N-Gain pretest and posttest control class. It can be concluded that there are significant learning method Start With A Question to increase students' critical thinking skills in ecosystem material.
\end{abstract}

Keywords: Learning Start With A Question, Critical Thinking Ability, Ekosisem

\section{Pendahuluan}

Berdasarkan hasil wawacara kepada guru di MTs N Plered terdapat beberapa masalah siswa di sekolah ini yaitu, rendahnya siswa yang aktif di kelas, rendahnya kemampuan berpikir kritis siswa dalam proses pembelajaran, kurangnya variasi model pembelajaran yang diterapkan guru di dalam kelas, dan
KKM siswa kelas VII d MTs.N Plered pada pelajaran IPA banyak di bawah KKM, KKM nya yaitu 07,00. Dengan demikian peneliti menggunakan metode Learning Start With A Question untuk meningkatkan keatifan bertanya siswa dan berpikir kritis siswa di kelas. Metode Learning Start With A Question adalah suatu metode pembelajaran aktif dalam 
bertanya, dimana siswa dilibatkan langsung dalam proses pembelajaran. Pada metode ini siswa dituntut untuk aktif bertanya terutama pada awal pembelajaran, oleh karena itu siswa diminta untuk mempelajari terlebih dahulu materi yang akan disampaikan oleh guru. Aktif bertanya pada awal pembelajaran akan merangsang siswa untuk berpikir kritis tentang materi yang akan di sampaikan. Metode ini juga menerapkan pola belajar dengan merangsang siswa untuk bertanya tentang materi yang akan diajarkan.

Untuk menuju hidup yang lebih berarti, seseorang tidak dapat melarikan diri dari berpikir dan berpikir secara kritis menjadikan hidup lebih bermakna. Berpikir kritis ini merupakan berpikir tingkat tinggi. Jika siswa terbiasa dengan berpikir kritis apalagi dibiasakan sejak muda tentunya dimulai dengan yang lebih sederhana atau disesuaikan dengan porsi usia dan mental siswa atau ditingkat dasar (SD) atau ditingkat sekolah menengah pertama (SMP), maka ketika siswa tersebut sudah mencapai tingkat tinggi atau tingkat sekolah menengah atas (SMA) dan sampai tingkat seterusnya. Maka siswa akan siap menghadapi masa depan dengan pemikiran yang mampu memecahkan masalah dengan baik, membuat solusi yang matang dan mampu mempertahankan kebenaran dalam berbagai permasalahan. Indikator berpikir kritis yang digunakan dalam penelitian ini adalah indikator berpikir kritis menurut Ennis (2011 : 1-4) yang telah dikelompokkan menjadi lima sub indikator, yaitu :

1. Memberikan penjelasan sederhana.

2. Membuat bentuk definisi.

3. Mengidentifikasi atau merumuskan pertanyaan

4. Kemampuan memberikan alasan

5. Menyebutkan contoh

\section{Metode Penelitian}

Metode yang digunakan dalam penelitian ini adalah metode quasi eksperimental dengan desain penelitiannya nonequivalent control group design. Populasinya adalah seluruh siswa kelas VII MTsN Plered-Purwakarta sebanyak lima kelas yaitu kelas VII-A sampai kelas VII-E. Sampel yang diambil yaitu siswa kelas VII-A dan kelas VII-D yang dipilih dengan teknik pengambilan purposive sample. Kelas VII-D sebagai kelas eksperimen dan kelas VII-A sebagai kelas kontrol yang masing-masing kelas terdiri dari 35 siswa. Teknik pengumpulan data diperoleh dari tes (pretest dan postest) dan nontes (angket dan lembar observasi). Pengolahan data dilakukan dengan analisis nonparametik yaitu uji mann-whitney.

\section{Hasil Penelitian dan Pembahasan}

Keterlaksanaan proses pembelajaran aktivitas guru dan siswa dengan menggunakan metode Learning Start With A Question dapat dilihat pada tabel 1:

Tabel 1 Rata-rata Nilai Keterlaksanaan Pembelajaran Menggunakan Metode Learning Start With A Question

\begin{tabular}{|c|c|c|c|c|}
\hline \multirow{2}{*}{$\begin{array}{c}\text { Perte } \\
\text { muan } \\
\text { ke- }\end{array}$} & \multicolumn{4}{|c|}{ Keterlaksanaan pembelajaran } \\
\hline & $\begin{array}{c}\text { Skor } \\
\text { observ } \\
\text { asi }\end{array}$ & $\begin{array}{c}\text { Skor } \\
\text { maksim } \\
\text { al }\end{array}$ & $\begin{array}{l}\text { Presen } \\
\text { tase }\end{array}$ & Kriteria \\
\hline 1 & 20 & 20 & 100 & $\begin{array}{c}\text { Sangat } \\
\text { Baik }\end{array}$ \\
\hline 2 & 17 & 18 & 94 & $\begin{array}{c}\text { Sangat } \\
\text { Baik }\end{array}$ \\
\hline 3 & 13 & 15 & 86 & $\begin{array}{c}\text { Sangat } \\
\text { Baik }\end{array}$ \\
\hline \multicolumn{3}{|c|}{ Rata-rata } & 93 & $\begin{array}{c}\text { Sangat } \\
\text { Baik }\end{array}$ \\
\hline
\end{tabular}

Keterlaksanaan menggunakan metode Learning Start With A Question pada materi ekosistem diperoleh melalui lembar keterlaksanaan pembelajaran yang meliputi aktivitas guru dan siswa dalam proses pembelajaran dengan prosedur metode Learning Start With A Question. Dari hasil penelitian dapat dilihat bahwa keterlaksanaan pembelajaran dengan menggunakan metode Learning Start With A Question memiliki nilai keterlaksanaan rata-rata $93 \%$. Nilai berada pada rentang 
80\%-100\% menurut Arikunto (2006:265) keterlaksanaan proses pembelajaran biologi pada materi ekosistem tergolong sangat baik. Data ini menunjukkan bahwa pembelajaran telah sesuai dengan indikator keterlaksanaan pembelajaran menggunakan metode Learning Start With A Question yang terdapat dalam lembar keterlaksanaan pembelajaran.

Berdasarkan tabel 1 didapat hasil rata-rata nilai keterlaksanaan pembelajaran sebesar 93\% dengan kriteria sangat baik. Data tersebut dapat pula dilihat dalam bentuk diagram batang pada gambar 1 berikut.

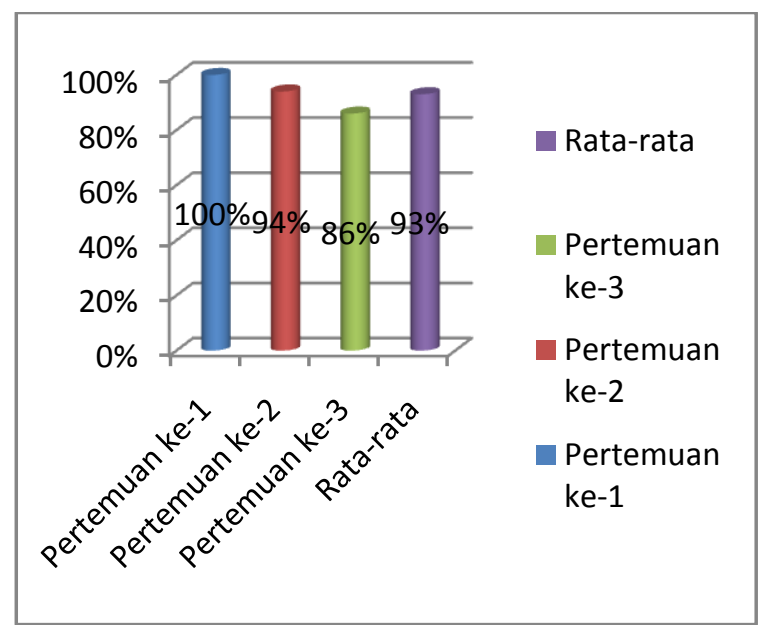

Gambar 1. Diagram Batang Rata-Rata Hasil Penilaian Keterlaksanaan Pembelajaran Menggunakan Metode Learning Start With A Question

Kemampuan berpikir kritis siswa di ukur dengan menggunakan tes formatif yaitu pretest dan posttest berbentuk esei sebanyak 10 soal. Hasil analisis statistik skor pretest dan posttest yang diperoleh dapat dilihat pada tabel 2 di bawah ini.

Tabel 2 Rata-Rata Keterampilan Berpikir Kritis Siswa dengan Menggunakan Metode Learning Start With A Question

\begin{tabular}{|c|c|c|c|c|}
\hline Nilai & Pretest & Posttest & $\begin{array}{c}\text { N- } \\
\text { Gain }\end{array}$ & $\begin{array}{c}\text { Katego } \\
\text { ri }\end{array}$ \\
\hline
\end{tabular}

\begin{tabular}{|c|c|c|c|c|}
\multicolumn{1}{c}{ dapat } & \multicolumn{2}{c}{ diinterpretasikan } & bahwa \\
\hline $\begin{array}{c}\text { Rata- } \\
\text { rata }\end{array}$ & 27,21 & 67,08 & 0,54 & Sedang \\
\hline
\end{tabular}

Berdasarkan tabel 2 di atas dapat diketahui bahwa rata-rata peningkatan kemampuan berpikir kritis siswa termasuk pada kategori sedang dengan nilai rata-rata $\mathrm{N}$-Gain sebesar 0,54. Dari tabel 2 tersebut dapat diilustrasikan dengan diagram batang seperti pada gambar 2 di bawah ini.

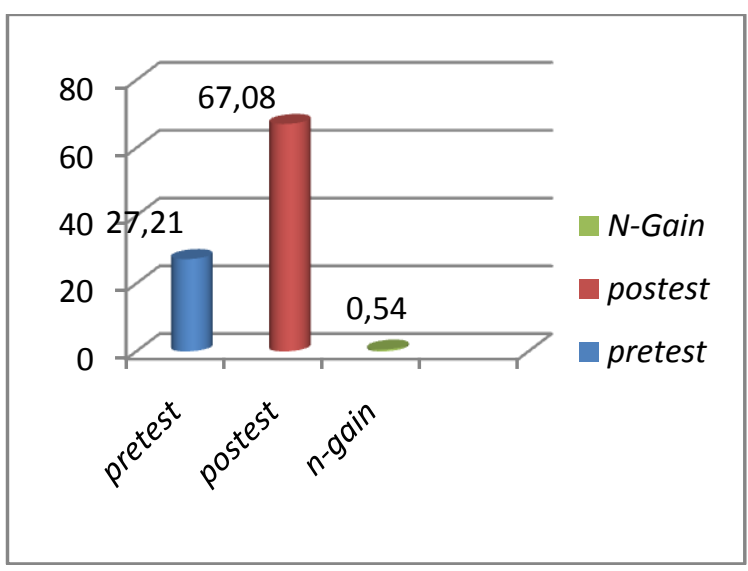

Gambar 2 Diagram Batang Rata-Rata Kemampuan Berpikir Kritis Siswa dengan Menggunakan Metode LearningStart With A Question.

Adapun rincian banyaknya siswa yang mengalami peningkatan tiap kategori peningkatan disajikan pada tabel 3 dibawah ini :

Tabel 3 Presentase Banyaknya Siswa Setiap Kategori Peningkatan

\begin{tabular}{|c|c|c|c|}
\hline No & $\begin{array}{c}\text { Banyaknya } \\
\text { Siswa }\end{array}$ & Kategori & Presentase \\
\hline $\mathbf{1}$ & 11 & Tinggi & $31.43 \%$ \\
\hline $\mathbf{2}$ & 19 & Sedang & $54.29 \%$ \\
\hline $\mathbf{3}$ & 5 & Rendah & $14.29 \%$ \\
\hline
\end{tabular}

Hasil analisis statistik skor pretest dan posttest yang didapat dari siswa kelas kontrol yang tanpa menggunakan metode Learning Start With A Question dalam pembelajaran ekosistem dapat dilihat pada tabel 4 di bawah ini. 
Tabel 4 Rata-Rata Kemampuan Berpikir Kritis Siswa Tanpa Menggunakan Metode Learning Start With A Question

\begin{tabular}{|c|c|c|c|c|}
\hline Nilai & Pretest & Posttest & $\begin{array}{c}\text { N- } \\
\text { Gain }\end{array}$ & $\begin{array}{c}\text { Katego } \\
\text { ri }\end{array}$ \\
\hline $\begin{array}{c}\text { Rata } \\
\text {-rata }\end{array}$ & 27,75 & 63,6 & 0,49 & Sedang \\
\hline
\end{tabular}

Berdasarkan data tabel dapat diketahui bahwa rata-rata peningkatan kemampuan berpikir kritis siswa termasuk pada kategori sedang dengan nilai rata-rata N-Gainnya sebesar 0,49. Dari tabel 3.4 dapat diilustrasikan dengan diagram batang seperti pada gambar di bawah ini :

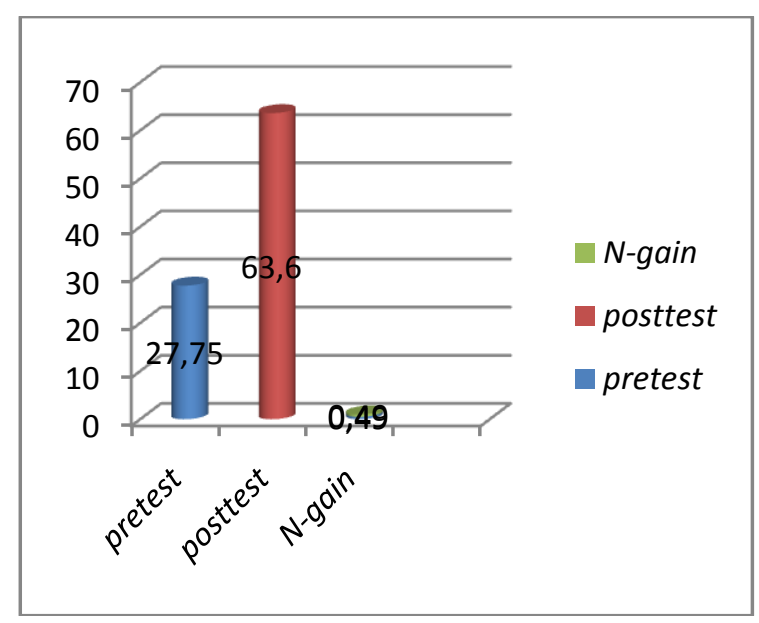

Gambar 3 Diagram Batang Rata-Rata Hasil Kemampuan Berpikir Kritis Siswa Tanpa Menggunakan Metode Learning Start With A Question.

Adapun rincian banyaknya siswa yang mengalami peningkatan tiap kategori peningkatan disajikan pada tabel berikut ini:

Tabel 5 Presentase Bangnyaknya Siswa Setiap Kategori Peningkatan

\begin{tabular}{|c|c|c|c|}
\hline No & $\begin{array}{c}\text { Banyaknya } \\
\text { Siswa }\end{array}$ & Kategori & Presentase \\
\hline 1 & 2 & Tinggi & $5,71 \%$ \\
\hline
\end{tabular}

\begin{tabular}{|c|c|c|c|}
\hline 2 & 30 & Sedang & $85,71 \%$ \\
\hline 3 & 3 & Rendah & $8,57 \%$ \\
\hline
\end{tabular}

Berdasarkan tabel diketahui bahwa banyaknya siswa yang peningkatan kemampuan berpikir kritis tinggi sebanyak 2 orang dengan presentase $5,71 \%, 30$ orang pada kategori sedang dengan presentase $85,71 \%$ dan pada kategori rendah berjumlah 3 orang dengan presentase $8,57 \%$.

Pengaruh penggunaan metode Learning Start With A Question terhadap kemampuan berpikir kritis siswa dapat dinilai dari nilai pretest, pretest dan $\mathrm{N}$ Gain keseluruhan siswa kelas eksperimen dan kelas kontrol.

Tabel 6 Keterampilan Berpikir Kritis Siswa dengan Menggunakan Metode Learning Start With A Question

\begin{tabular}{|c|c|c|c|c|}
\hline \multirow{2}{*}{ Kelas } & \multicolumn{3}{|c|}{ Skor Rata-rata } & \multirow{2}{*}{$\begin{array}{c}\text { Interpr } \\
\text { etasi }\end{array}$} \\
\cline { 2 - 4 } & Pretest & Posttest & $\begin{array}{c}\text { N- } \\
\text { Gain }\end{array}$ & \\
\hline $\begin{array}{c}\text { Ekspe } \\
\text { rimen }\end{array}$ & 27,21 & 68,08 & 0,54 & Sedang \\
\hline $\begin{array}{c}\text { Kontr } \\
\text { ol }\end{array}$ & 27,75 & 63,6 & 0,49 & Sedang \\
\hline
\end{tabular}

Berdasarkan perhitungan yang telah dilakukan, kelas eksperimen memiliki nilai rata-rata posttest sebesar 68,08 , Nilai ratarata posttest kelas kontrol 63,06, nilai ratarata Pretest kelas eksperimen 27,21 dan kontrol 27,75. N-Gain kelas eksperimen 0,54 kategori sedang dan $\mathrm{N}$-Gain kelas kontrol 0,49 kategori sedang. Setelah nilai rata-rata posttest, pretest dan $\mathrm{N}$-Gain diketahui, langkah selanjutnya adalah melakukan perhitungan uji normalitas, uji homogenitas dan uji hipotesis. Jika data perhitungan normalitas berdistribusi normal, maka dilanjutkan dengan uji homogenitas dan uji hipotesis. Akan tetapi, apabila data perhitungan normalitas tidak berdistribusi normal, maka langsung dilakukan uji hipotesis dengan statistik nonparametik yaitu uji mann-whitney 
dengan tujuan untuk mengetahui pengaruh metode Learning start with a question terhadap kemampuan berpikir kritis siswa. Dari tabel 6 tersebut dapat diilustrasikan dengan diagram batang seperti pada gambar di bawah ini :

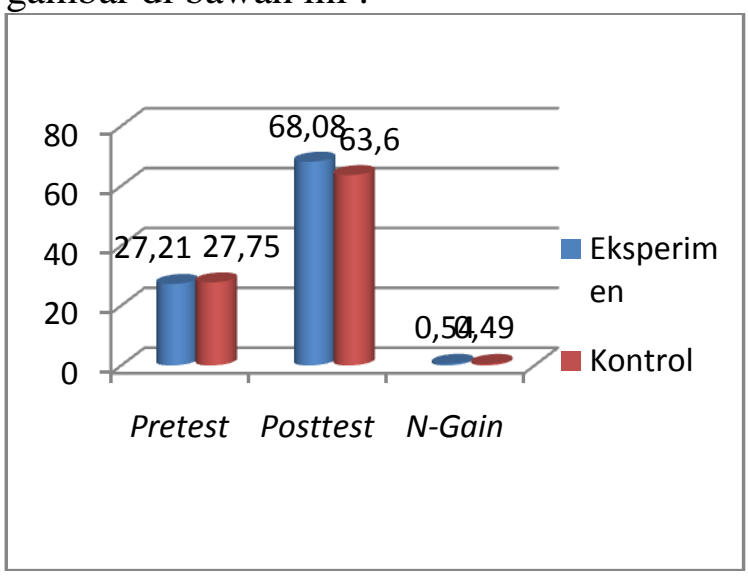

Gambar 4 Diagram Batang Skor Rata-rata Pretest,Posttest, N-Gain Siswa Kelas Eksperimen dan Kelas Kontrol

Tabel 7 Ringkasan Hasil Analisis Uji Normalitas

\begin{tabular}{|c|c|c|c|c|c|}
\hline \multirow{3}{*}{$\begin{array}{l}\text { Dat } \\
\text { a }\end{array}$} & \multicolumn{4}{|c|}{ Kelas } & \multirow{3}{*}{$\begin{array}{c}\text { Keteranga } \\
\mathbf{n}\end{array}$} \\
\hline & \multicolumn{2}{|c|}{$\begin{array}{c}\text { Eksperim } \\
\text { en }\end{array}$} & \multicolumn{2}{|c|}{ Kontrol } & \\
\hline & $\begin{array}{c}\mathrm{X}^{2} \\
\text { hitu } \\
\text { ng }\end{array}$ & $\begin{array}{c}X^{2} \\
\text { tab } \\
\text { el }\end{array}$ & $\begin{array}{c}\mathrm{X}^{2} \\
\text { hitu } \\
\text { ng }\end{array}$ & $\begin{array}{c}\mathrm{X}^{2} \\
\text { tabel }\end{array}$ & \\
\hline $\begin{array}{l}\mathrm{N}- \\
\text { Gai } \\
\mathrm{n}\end{array}$ & $\begin{array}{l}10, \\
23\end{array}$ & $\begin{array}{c}7,8 \\
1\end{array}$ & $\begin{array}{c}3,6 \\
1\end{array}$ & 7,81 & $\begin{array}{c}\text { Salah satu } \\
\text { data tidak } \\
\text { normal } \\
\text { (dilanjutkan } \\
\text { dengan Uji } \\
\text { Mann- } \\
\text { Whitney) }\end{array}$ \\
\hline
\end{tabular}

Karena ada salah satu data yang tidak normal maka, untuk data N-Gain akan dilakukan uji Mann-Whitney.

Berdasarkan tabel 8 di atas, dapat diketahui bahwa nilai $Z_{\text {hitung }}=1,98>Z_{\text {tabel }}$ $=1,65$, maka $\mathrm{H}_{0}$ ditolak dan $\mathrm{H}_{\mathrm{a}}$ diterima artinya terdapat perbedaan antara nilai NGain pretest dan posttest kelas eksperimen dengan N-Gain pretest dan posttest kelas kontrol. Hal tersebut dapat disimpulkan bahwa terdapat pengaruh metode Learning Start With A Question terhadap peningkatan kemampuan berpikir kritis siswa.

Tabel 8 Hasil Analisis Uji Mann-Whitney untuk Skor N-Gain Kelas Eksperimen dan Kelas Kontrol

\begin{tabular}{|c|c|c|c|}
\hline Data & $\mathbf{Z}_{\text {hitu }}$ & $\mathbf{Z}_{\text {tabe }}$ & Keterangan \\
\hline $\begin{array}{l}\mathrm{N}- \\
\text { Gain }\end{array}$ & 1,98 & 1,65 & $\begin{array}{c}\text { Jika taraf kesalahan 5\%, } \\
\text { Ha diterima yang artinya } \\
\text { terdapat peningkatan } \\
\text { yang signifikan antara } \\
\text { skor N-Gain kelas } \\
\text { eksperimen dan kelas } \\
\text { kontrol. Maka } \\
\text { pembelajaran dengan } \\
\text { menggunakan metode } \\
\text { Learning Start With A } \\
\text { Question berpengaruh } \\
\text { positif (terdapat } \\
\text { pengaruh metode LSQ } \\
\text { terhadap peningkatan } \\
\text { kemampuan berpikir } \\
\text { kritis siswa). }\end{array}$ \\
\hline
\end{tabular}

Analisis angket diukur dengan menggunakan skala Guttman. Angket yang diberikan kepada siswa terdapat 22 item pertanyaan yang harus di jawab siswa dengan 2 pilihan "Ya" atau "TIdak". Karena jawabannya hanya Ya dan Tidak maka dihitungnya menggunakan skala guttman, jawabannya yang ingin mendapatkan jawaban yang tegas terhadap suatu permasalahan dalam pernyataan (Indira, 2013:1).

Berdasarkan tabel 9 tanggapan siswa terhadap pembelajaran yang menggunakan metode Learning Start With A Question, diperoleh rata-rata sebanyak 69\% dengan kualifikasi "mendekati ya". Hal ini menunjukan siswa menyukai pembelajaran yang menggunakan metode Learning Start With A Question. Dari hasil analisis angket atau tanggapan siswa terhadap pembelajaran dengan menggunakan metode Learning Start With A Question menunjukkan bahwa siswa memiliki respon baik. Ini bisa dilihat dari nilai rata-rata nilai angket $69 \%$ dengan 
kualifikasi mendekati ya. Nilai tertinggi dari tanggapan siswa terdapat pada no 6, siswa menjawab ya sebanyak 35 orang atau seluruh siswa menjawab ya, jika dipersenkan yaitu 100\% siswa menjawab ya dengan pertanyaan "Apakah dengan menggaris bawahi isi hand out anda dilatih untuk teliti dalam memahami pembelajaran pada materi ekosistem?". dengan demikian respon siswa sangat baik, siswa merasa dengan tahapan yang ada pada metode Learning Start With A Question yaitu menggarisbawahi isi hand out siswa dilatih untuk teliti dalam memahami pembelajaran. Sedangkan nilai terendah pada pertanyaan no 10, siswa yang menjawab ya hanya 1 orang dengan presentase $2 \%$ dengan pertanyaan "apakah dengan pembelajaran menggunakan metode Learning Start With A Question (LSQ) materi ekosistem menjadi membosankan?" dengan demikian siswa tidak merasa bosan ketika guru menyampaikan pembelajaran dengan metode Learning Start With A Question.

Tabel 9 Persentase Tanggapan Siswa terhadap Pembelajaran dengan Metode Learning Start With A Question pada Materi Ekosistem

\begin{tabular}{|c|c|c|c|c|}
\hline Item Pertanyaan & Jawaban Ya & $(\%)$ & Kualifikasi & Jawaban Tidak \\
\hline P1 & 10 & 28 & Mendekati tidak & 25 \\
\hline $\mathbf{P 2}$ & 13 & 37 & Mendekati tidak & 22 \\
\hline P3 & 33 & 94 & Mendekati ya & 2 \\
\hline P4 & 31 & 88 & Mendekati ya & 4 \\
\hline P5 & 34 & 97 & Mendekati ya & 1 \\
\hline P6 & 35 & 100 & Mendekati ya & 0 \\
\hline P7 & 31 & 88 & Mendekati ya & 4 \\
\hline P8 & 32 & 91 & Mendekati ya & 3 \\
\hline P9 & 33 & 94 & Mendekati ya & 2 \\
\hline P10 & 1 & 2 & Mendekati tidak & 34 \\
\hline P11 & 21 & 60 & Mendekati ya & 14 \\
\hline P12 & 32 & 91 & Mendekati ya & 3 \\
\hline P13 & 4 & 11 & Mendekati tidak & 31 \\
\hline P14 & 31 & 88 & Mendekati ya & 4 \\
\hline P15 & 28 & 80 & Mendekati ya & 7 \\
\hline P16 & 10 & 28 & Mendekati tidak & 25 \\
\hline P17 & 33 & 94 & Mendekati ya & 2 \\
\hline P18 & 31 & 88 & Mendekati ya & 4 \\
\hline P19 & 31 & 88 & Mendekati ya & 4 \\
\hline P20 & 26 & 74 & Mendekati ya & 9 \\
\hline P21 & 14 & 40 & Mendekati tidak & 21 \\
\hline $\mathbf{P 2 2}$ & 21 & 60 & Mendekati ya & 14 \\
\hline Total & 535 & 1521 & & 235 \\
\hline Rata_rata & 24,31 & 69 & & 10,68 \\
\hline
\end{tabular}




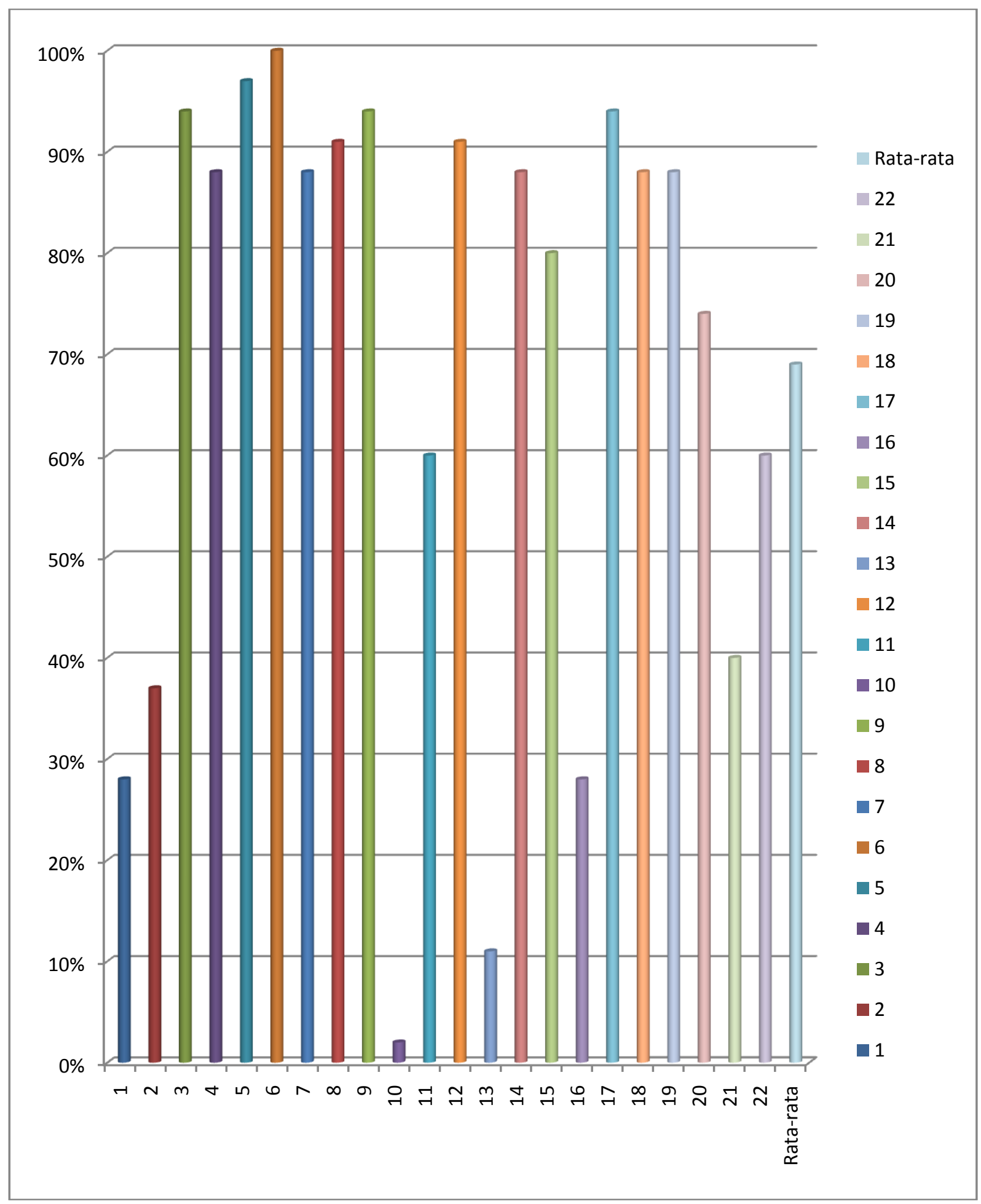

Gambar 5 Diagram Batang Tanggapan Siswa terhadap Pembelajaran yang Menggunakan Metode Learning Start With A Question

4. Kesimpulan dan Saran
Berdasarkan hasil penelitian tentang pengaruh metode learning start 
with a question terhadap peningkatan kemampuan berpikir kritis siswa pada materi ekosistem di kelas VII MTs.N Plered-Purwakarta. maka dapat diambil kesimpulan yaitu: (1) Keterlaksanaan proses pembelajaran pada kelas yang menggunakan metode learning start with a question pada lembar keterlaksanaan pembelajaran dengan rata-rata 93\% dengan kategori sangat baik. (2) Kemampuan berpikir kritis siswa dengan menggunakan metode Learning Start With A Question dilihat dari hasil pretest dan posttest. Hasil rata-rata pretest 25,21 sedangkan hasil rata-rata posttest 67,08 dengan rata rata $\mathrm{N}$-Gain nya 0,54 . (3) Terdapat pengaruh peningkatan kemampuan berpikir kritis siswa pada materi ekosistem dengan metode Learning Start With A Question. (4) Secara umum respon atau tanggapan siswa terhadap pembelajaran dengan metode Learning Start With A Question pada materi ekosistem diperoleh rata-rata $69 \%$ dengan kualifikasi "mendekati ya". Ini menunjukkan siswa menyukai pembelajaran dengan menggunakan metode Learning Start With A Question.

Berdasarkan hasil penelitian, pembahasan dan kesimpulan yang telah dikemukakan di atas, maka diajukan saran sebagai berikut: (1) Karena metode Learning Start With A Question memerlukan waktu yang banyak, maka bagi guru yang akan menggunakan metode Learning Start With A Question disarankan agar bisa mengefektifkan waktu sebaik mungkin. (2) Bagi guru yang akan menggunakan metode Learning Start With A Question disarankan untuk dicobakan pada materi lain untuk meningkatkan kemampuan berpikir kritis siswa. (3) Bagi guru yang ingin mencoba menerapkan metode pembelajaran yang baru bagi peserta didik, metode Learning Start With A Question ini dapat dijadikan alternatif metode pembelajaran di kelas dalam rangka meningkatkan kemampuan berpikir kritis siswa. (4) Perangkat pembelajaran maupun sumber belajar hendakya dirancang dengan sebaik-baiknya agar pelaksanaan kegiatan pembelajaran berlangsung dengan baik dan tercapainya tujuan pembelajaran.

\section{Daftar Pustaka}

Ennis, Robert H. (2011). The Nature Of Critical Thinking: An Outline Of Critical Thinking Disposition And Abilities. Urban-Campaign: University Of Illinois. $\mathrm{Http} / /$ :faculty.education.Illinois.edu /rhenis/documents/thenatureofcritic althinking. Diakses tanggal 20 Juni 2014.

Indira. (2013). Pengukuran Skala Guttman Tradisional. [online] http://www.slideshare.net/indirakan iaputri/pengukuran-skala-guttmantradisional-29376589. Diakses tanggal 27 Juni 2014.

Slameto. (2010). Belajar dan FactorFaktor Yang Mempengaruhinya. Jakarta :PT Rineka Cipta.

Suhana dan Hanafiah. (2009). Konsep Strategi Pembelajaran. Bandung : PT Refika Aditama.

Syah,M. (2010). Psikologi pendidikan .Bandung :PT Remaja rosdakarya. 